\title{
Are conservation assessments of threatened species reliable? Updated distribution of the Endangered Sardinian newt Euproctus platycephalus and implications for Red List assessments of Italian amphibians
}

\author{
Leonardo Vignoli, Daniele Macale, Luca Luiselli \\ Roberta LeCis and PaOlo Casula
}

\begin{abstract}
Assessing and updating the extinction risk and conservation status of species and populations is paramount to guide management strategies. Maintaining up-to-date and realistic geographical distribution maps of individual species is one aspect of this. We report an updated distribution for an Italian island endemic amphibian, the Sardinian newt Euproctus platycephalus, categorized as Endangered on the IUCN global and national Red Lists. The distribution of E. platycephalus was reassessed by means of visual surveys, questionnaires, interviews and scientific literature. The species was found over a geographical range comparable to that used for the IUCN assessment but we recorded a significantly larger number of populations ( $57 \mathrm{vs} 14$ ). There was no appreciable difference in the species' Extent of Occurrence between 1972-1974 and 2010-2015. Area of Occupancy increased between past (1972-1974 and 19992000) and present (2010-2015) distribution records. Based on this updated distribution and considering that several new populations have been found, the distribution of the species may still be underestimated. Given the novel distribution data provided here and the need for new long-term demographic data, we recommend that the conservation status of E. platycephalus be reassessed. In the Italian national Red List a potential overstatement of extinction risk is evident for other amphibian species, possibly because the information used in their assessment is deficient.
\end{abstract}

Leonardo Vignoli (Corresponding author) Dipartimento di Scienze, Università degli studi Roma Tre, Viale Guglielmo, Marconi 446-00146, Rome, Italy E-mail leonardo.vignoli@uniroma3.it

Daniele Macale Fondazione Bioparco di Roma, Viale del Giardino Zoologico, Rome, Italy

LuCA Luiselli* Niger Delta Ecology and Biodiversity Conservation Unit, Department of Applied and Environmental Biology, Rivers State University of Science and Technology, Port Harcourt, Nigeria

RoberTa Lecis Dipartimento Medicina Veterinaria, Università di Sassari, Sassari, Italy

Paolo Casula Ente Foreste della Sardegna, Direzione Generale, Servizio Tecnico, Cagliari, Italy

${ }^{*}$ Also at: Nigerian Agip Oil Company (Eni group Environmental Department), Rome, Italy

Received 7 July 2015. Revision requested 7 August 2015.

Accepted 8 December 2015. First published online 25 April 2016.
Considering that monitoring rare and elusive species is costly and time consuming we recommend more extensive use of multiple sources of information for Red List assessments.

Keywords Euproctus platycephalus, island endemic, Italy, newt, Red List, Sardinia, species distribution

To view supplementary material for this article, please visit http://dx.doi.org/10.1017/Soo30605315001416

\section{Introduction}

Tn theory species that are both rare and endemic face the 1 highest risk of extinction (Primack, 2006). Furthermore, island species are generally at higher risk than mainland taxa because of their usually smaller range and the comparatively higher risk posed by the introduction of predators, diseases and other threats (Manne et al., 1999; Simberloff, 2000; but see Manne et al., 1999, for passerine birds). Evaluating and ranking the extinction risk of endemic and rare species is important to guide conservation management at both the global and local scales (e.g. Andreone \& Luiselli, 2000; Cox \& Temple, 2009; Luiselli, 2009; Tomović et al., 2015). The IUCN Red List is used extensively, not only to guide conservation actions but also to inform the allocation of limited funding resources for nature conservation (IUCN, 2015). The IUCN assessment criteria rely primarily on distribution data (i.e. criteria $\mathrm{B}$ and $\mathrm{D}_{2}$ ), estimations of population parameters (population size, reduction and decline rates; criteria $\mathrm{A}, \mathrm{C}$ and $\mathrm{D} 1$ ), and quantitative analyses (i.e. probability of extinction; criterion E). In most cases these criteria are assessed by means of expert-driven approaches, and a species' true conservation status and risk of extinction may be evaluated incorrectly (Amori et al., 2014). To minimize this problem IUCN revises species datasets on a regular basis, with evaluation of all incoming novel data. Thus it is crucial to update species' conservation status data with new evidence from field surveys.

Amphibians are one of the most threatened animal taxa (Stuart et al., 2004) despite increasing conservation efforts (Hoffmann et al., 2010). An assessment of the entire 
group (> 7,000 species; IUCN SSC Amphibian Specialist Group, 2011) found that nearly one-third of amphibian species are under threat, $2 \%$ are believed to have gone extinct and almost half of the known species are declining.

We present novel data on the distribution of the endemic Sardinian newt Euproctus platycephalus (Amphibia, Salamandrinae). The genus Euproctus comprises only two species, restricted to Sardinia and Corsica (Carranza \& Amat, 2005). The Sardinian newt is categorized as Endangered on the IUCN Red List (Romano et al., 2009) because its Area of Occupancy (AOO) is $<500 \mathrm{~km}^{2}$, its distribution is fragmented, and there is an ongoing decline in the extent and quality of its habitat and in the number of subpopulations. During 1999-2001 it was found at 14 sites, whereas C. 1991 it was present at 30 sites (and even then it was absent from nine other sites where it had been observed previously).

We re-evaluated the current distribution of the species based on field surveys carried out during 2010-2015. By comparison with available historical data (Alcher, 1975; Lecis \& Norris, 2003) we then evaluated the conservation status of the species. Specifically we address the following key questions: (1) Does the historical distribution of the species overlap its actual distribution? (2) What is the range trend of the species across presence sites where long-term surveys have been carried out? (3) Is there any geographical pattern in the observed range trend?

We discuss the evaluation of other Italian amphibian species on the Italian Red List, highlighting problems in the data gathering process of global and national Red List assessments, and we provide recommendations for a more extensive use of local knowledge or opportunistic data for Red List assessments.

\section{Study area}

The field study was carried out throughout the species' range in Sardinia (Fig. 1). All known localities of occurrence were recorded by examining scientific literature, grey literature, educational publications, books, anecdotal reports, and our own questionnaires. Overall we identified 205 sites with locality description, place name or geographical coordinates. Localities for which there were at least two independent records in the previous 20 years were designated for further inspection by field surveys. Sixty-seven sites satisfied this criterion and were surveyed at least once during 2010-2015. As the field surveys were carried out opportunistically according to the schedules of various independent projects, the number of visits per site varied among localities (mean $=2.16 \pm$ SD 1.79, range 1-7; visits per site during the same year: $1.21 \pm \mathrm{SD} 0.41$, range $1-3$ ).

\section{Methods}

Questionnaire Local ecological knowledge is a useful source of information about species' distribution and abundance
(Huntington, 2000; White et al., 2005; Anadón et al., 2009; Franco et al., 2013), and questionnaires have been used previously to study the distribution of the Sardinian newt (Lecis \& Norris, 2003). The species' distribution was reassessed using questionnaires distributed extensively throughout the island (Casula et al., 2010; Supplementary Material 1) to gather data on when and where the species was observed, the locality, stream, years of observation, and number of individuals observed. The questionnaire was distributed to the following groups: forestry workers of the Sardinian forest management agency, Ente Foreste della Sardegna; patrol staff of the Corpo Forestale e di Vigilanza Ambientale; local wildlife experts and herpetologists; canyoning associations; and the general public via the SardegnaForeste website, which featured a news story on the Sardinian newt on its homepage, with a link to the questionnaire, for 1 month (SardegnaForeste, 2010). Overall we received 218 completed questionnaires with information on the presence of Sardinian newts.

Visual surveys We assessed the presence of newts at 67 sites by visual surveys during 2010-2015. The localities to be surveyed were identified based on information gathered from the questionnaires, subsequent interviews, literature, and $1: 25,000$ topographical maps. Surveys involved at least two observers hiking upstream for 2 hours. Observers generally walked along the creek and stopped to conduct a careful visual inspection when facilitated by slow-moving water (pools). Surveys were planned for warm, sunny days during April-November, according to the local climate and river regime. All mountainous areas thought to be inhabited by the newt (Table 1) were surveyed, with the following effort: 155 days per observer in 2010, 4 days per observer in 2011, 40 days per observer in 2012, 36 days per observer in 2013, 47 days per observer in 2014, and 15 days per observer in 2015. A study providing historical distribution data (Alcher, 1975) did not provide details on effort, thus impeding comparisons in terms of sampling efficiency and species detectability. For a study carried out during 1999-2001 (Lecis \& Norris, 2003) the mean effort was 60 days per observer per year.

Statistical analyses Past and present Extent of Occurrence (EOO) of E. platycephalus was estimated by means of a minimum convex polygon (using the polygon tool in Google Earth Pro v. 7.1.2.2041; Google Inc., Mountain View, USA), using the distribution maps provided in Alcher (1975) and Lecis \& Norris (2003). These maps were also used to estimate past $\mathrm{AOO}$ (the area within the EOO that is occupied by a taxon; IUCN, 2012). For the present AOO we used our map with the addition of data from Sotgiu et al. (2010) and de Pous et al. (2012). The appropriate scale to use when estimating $\mathrm{AOO}$ is 


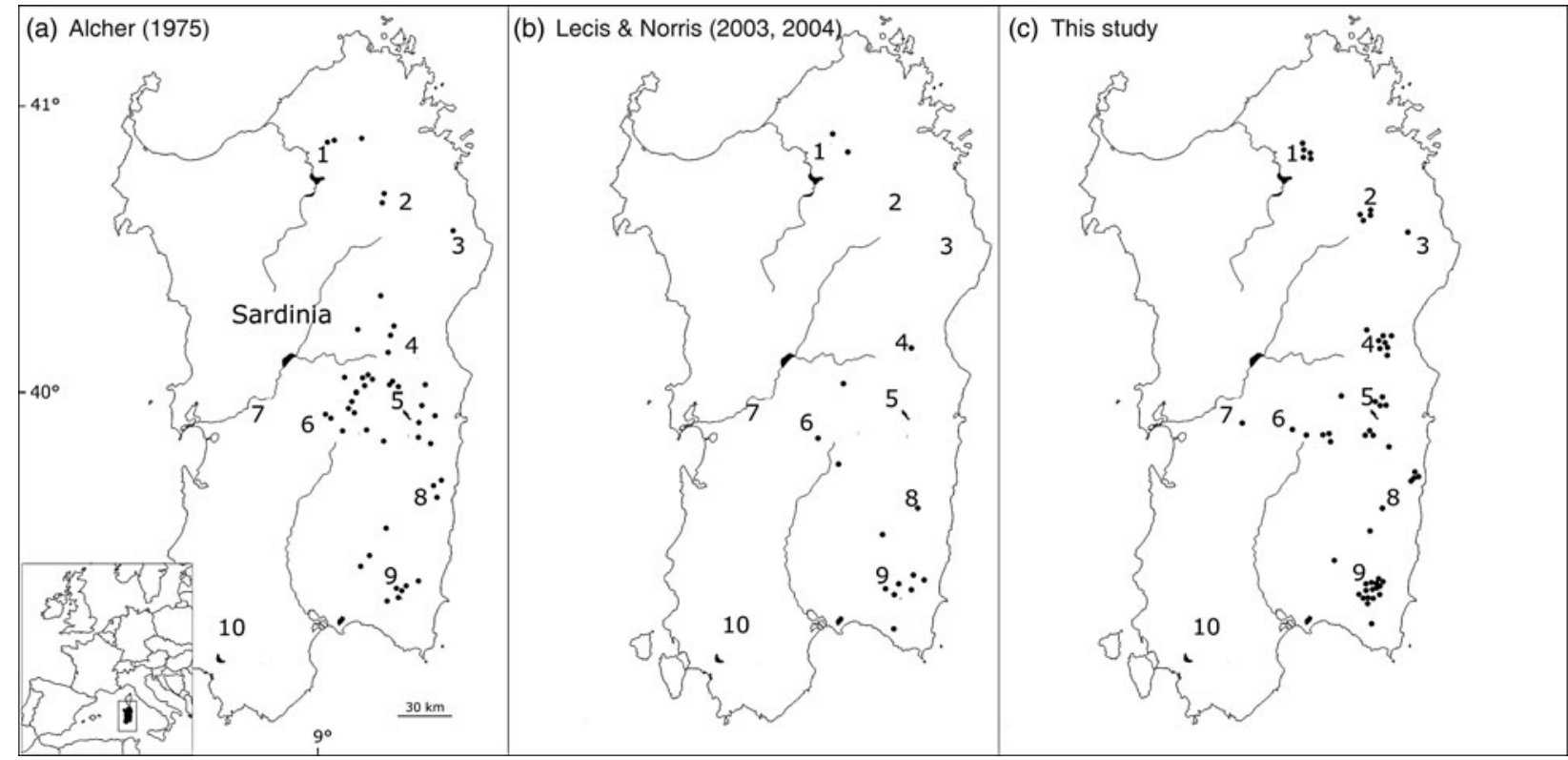

FIg. 1 Distribution of the Sardinian newt Euproctus platycephalus from (a) Alcher (1975), time range 1970-1973; (b) Lecis \& Norris (2003, 2004), time range 1999-2001; and (c) this study, time range 2010-2015. The numbers indicate the main districts where the species was recorded: 1, Limbara Mountain; 2, Altopiano Buddusò; 3, Albo Mountain; 4, Supramonte di Oliena; 5, Gennargentu Mountain; 6, Sarcidano; 7, Grighine; 8, Ogliastra; 9, Sarrabus-Gerrei; 10, Iglesiente (where the species' presence is known only from anecdotal records).

TABLE 1 Synopsis of the known sites of presence of the Sardinian newt Euproctus platycephalus over its whole range (Fig. 1), with district, no. of sites, overall presence, no. of surveyed years, no. of years since last sighting, no. of unconfirmed sites, and no. of newly discovered sites since the last published record (Lecis \& Norris, 2003).

\begin{tabular}{|c|c|c|c|c|c|c|}
\hline District & No. of sites ${ }^{1}$ & Overall presence $^{2}$ & $\begin{array}{l}\text { No. of } \\
\text { surveyed } \\
\text { years }^{3}\end{array}$ & $\begin{array}{l}\text { No. of years } \\
\text { since last } \\
\text { confirmed sighting }\end{array}$ & $\begin{array}{l}\text { No. of unconfirmed } \\
\text { sites (\%), mean no. } \\
\text { of years since last sighting }\end{array}$ & $\begin{array}{l}\text { No. of newly } \\
\text { discovered } \\
\text { sites }(\%)\end{array}$ \\
\hline $\begin{array}{c}\text { Limbara \& Albo } \\
\text { Mountains }\end{array}$ & 5 & $1991-2014$ & 23 & $0-3$ & $2(40), 6$ & 0 \\
\hline Altopiano Buddusò & 6 & 1982-2014 & 32 & $0-3$ & $1(17), 3$ & $2(33)$ \\
\hline Supramonte di Oliena & 9 & $1975-2015$ & 40 & 0 & 0 & $5(55)$ \\
\hline Gennargentu Mountain & 13 & $1985-2015$ & 30 & $0-1$ & 0 & $8(61)$ \\
\hline Sarcidano & 5 & 1975-2014 & 39 & 0 & $1(20), 9$ & $2(40)$ \\
\hline Grighine & 1 & 2015 & 1 & 0 & 0 & $1(100)$ \\
\hline Ogliastra & 7 & 1992-2015 & 23 & 0 & 0 & $1(100)$ \\
\hline Sarrabus-Gerrei & 17 & $1980-2015$ & 35 & 0 & $1(7), 9$ & $3(18)$ \\
\hline Iglesiente & 5 & $1998-2009$ & 16 & $6-16$ & $5(100), 12$ & 0 \\
\hline Total & 67 & & & & $8(13)$ & $17(28)$ \\
\hline
\end{tabular}

${ }^{1}$ Including those known historically and those newly discovered during recent surveys.

${ }^{2}$ Time span during which the species has been observed.

${ }^{3}$ Time span between first and last field observations in each district.

species-specific; we used a grid of $4 \mathrm{~km}^{2}$ cells, as recommended by IUCN for species occurring in and confined to linear habitats (e.g. shorelines, streams). As almost all the sites where the target species was present were in streams, with $>_{1}$ record per stream in many cases, and the mean length of the sampled streams was c. $1.5 \mathrm{~km}$, most of the sites considered were represented by more than one grid cell. Differences in the frequencies of confirmed vs unconfirmed presence sites were assessed by the $\chi^{2}$ test. All statistical analyses were performed using Statistica v. 8.o (StatSoft Inc., Tulsa, USA), with two tails and $\alpha$ set at 0.05 . 


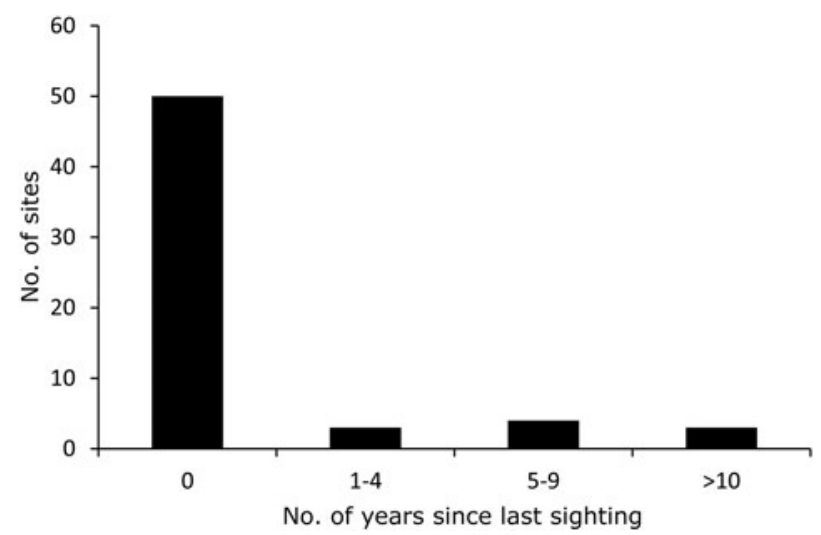

FIG. 2 Distribution of the sampled sites in terms of the no. of years since the last sighting of a Sardinian newt.

\section{Results}

The Sardinian newt was found at 57 sites throughout its range, including new as well as previously known and confirmed records (Table 1). Most (87.5\%) sites of historical presence of the species were confirmed by our surveys (Fig. 2). The number of confirmed sites was significantly higher than that of unconfirmed sites $\left(\chi^{2}=30.25, \mathrm{df}=1\right.$, $\mathrm{P}=0$ ), thus showing that the species is still extant in the majority of the areas where it was discovered some decades ago. Our surveys confirmed the presence of the species at sites where it had not been recorded since the unconfirmed reports of Lecis \& Norris (2003; Table 2).

In $1972-1974$ EOO was estimated to be c. $6,560 \mathrm{~km}^{2}$, in 1999-2001 c. $4,416 \mathrm{~km}^{2}$, and in $2010-2015$ c. $7,636 \mathrm{~km}^{2}$ (Fig. 1). If we include the records from Iglesiente (Casula et al., 2010) we estimate the current EOO for the species to be $11,514 \mathrm{~km}^{2}$. Using only our own data, the AOO for $2010-2015\left(408 \mathrm{~km}^{2}\right)$ was greater than that of previous studies. Compared with the AOO in $1972-1974\left(344 \mathrm{~km}^{2}\right)$ the difference was moderate (16\%) but compared with 1999-2001 $\left(112 \mathrm{~km}^{2}\right)$ it was significant $(72 \%)$. The AOO based on all recent records (i.e. including those not directly verified by the authors) is $520 \mathrm{~km}^{2}$.

\section{Discussion}

Is the current Red List status of the Sardinian newt supported by scientific evidence?

Our study is the most exhaustive and up-to-date assessment of the distribution of the Sardinian newt. The number of presence localities of the species reported here is greater than that of all previously published datasets, including those published in the 1970s, when the species was presumed to be less threatened ( 46 sites in Alcher, 1975; 14 verified by field survey in Lecis \& Norris, 2003; 34 in Sotgiu et al., 2010).
We found that the Sardinian newt is widespread across water basins in the mountains in the east of the island, and also discovered it at some new sites at sea level (Marina di Gairo). Moreover, we extended the western boundary of the species' known range by c. $23 \mathrm{~km}$ with the discovery of a new locality of presence (Grighine Mountain, Oristano Province; Table 1). Overall, our results mirror those of Alcher (1975) but differ from those of Lecis \& Norris (2003; 14 localities confirmed). The differences may be attributable to a difference in survey effort and site confirmation rate, as well as ecological factors (Lecis \& Norris, 2004).

Lecis \& Norris (2003) visited 36 sites, compared with our 64 , and their rate of confirmation of species presence was $38.9 \%$, compared with our $87.5 \%$. Our higher confirmation rate may be a result of our use of more detailed information to select survey localities. We also distributed questionnaires to several groups, whereas previous studies (Lecis \& Norris, 2003) targeted a single group (Corpo Forestale e di Vigilanza Ambientale). Records of species presence came mostly from Ente Foreste della Sardegna (70\%) and local wildlife experts and herpetologists (20\%), whereas only $10 \%$ of records came from Corpo Forestale e di Vigilanza Ambientale, canyoning associations and the internet (Casula et al., 2010). By gathering information from various sources we were able to select localities more likely to be inhabited by the species.

Given that we report a higher number of confirmed presence localities than previously reported and that several new populations have been discovered outside the known range (Table 1), we suggest that the distribution of the species may still be underestimated. Nonetheless, we propose that this updated distribution be considered as a snapshot of the actual distribution, not comparable to previous range estimations because of the variation in effort involved. Without further research to gather data on distribution and demography we cannot demonstrate any trend of decline or increase. In the absence of this information criteria $\mathrm{A}, \mathrm{C}$ and $\mathrm{E}$ cannot be used, nor can criterion $\mathrm{B}$ despite at least one sub-criterion being met.

The only area where the species is likely to be declining, if not already locally extinct, is the Iglesiente (Fig. 1), where it was recorded based on anecdotal information (the last record was in 2009; Casula et al., 2010). However, our surveys did not confirm the presence of the species there, nor did Alcher (1975) or Lecis \& Norris (2003). Details of the Iglesiente localities visited during 2010-2015 are in Supplementary Table S1.

Considering there are no demographic data available for any local population, and several new localities of presence were discovered (see also Sotgiu et al., 2010; de Pous et al., 2012), we question whether the current Red List status, assessed based on previous distributional data, is still supported. We do not suggest that the species is not threatened (it partially meets criterion $\mathrm{B}_{2}$ for categorization 
TABLE 2 Localities where Sardinian newt populations were present before 1991 but were unconfirmed by a later forestry station questionnaire (Lecis \& Norris, 2003a,b). We confirmed the presence of the species at all unconfirmed sites visited during our surveys.

\begin{tabular}{|c|c|c|c|c|}
\hline Locality $^{1}$ & Mountain system & Year & Source & This study \\
\hline $\begin{array}{l}\text { Burcei } \\
\text { (Rio Brabaisu) }\end{array}$ & Sette Fratelli & 1990 & Forest station observation & Confirmed \\
\hline $\begin{array}{l}\text { Muravera (Rio } \\
\text { Picocca) }\end{array}$ & Sette Fratelli & 1975 & Amphibiaweb $^{2}$ & Confirmed $^{3}$ \\
\hline Tertenia & Ogliastra & 1985 & Local communication & Confirmed \\
\hline Benetutti & Goceano & 1990 & Forest station observation & Not visited \\
\hline Bolotana & Marghine & 1990 & Local communication & Not visited \\
\hline AlàdeiSardi & Monti di Alà & 1974 & Alcher (1975) & Confirmed \\
\hline Siniscola & Monti di Alà & 1974 & Alcher (1975) & Confirmed \\
\hline Nuoro & Gennargentu & 1974 & Alcher (1975) & Confirmed \\
\hline Orgosolo & Gennargentu & 1974 & Alcher (1975) & New site discovered \\
\hline Arzana & Gennargentu & 1974 & Alcher (1975) & Confirmed \\
\hline Gairo & Ogliastra & 1974 & Alcher (1975) & Confirmed \\
\hline
\end{tabular}

${ }^{1}$ For the localities of Nuoro, Orgosolo and Arzana we cannot be certain that our confirmed sites exactly matched those originally cited in Alcher (1975). ${ }^{2}$ This source is ambiguous.

${ }^{3}$ Confirmed in the upper portion of the river Rio Picocca.

as Endangered, probably because there are insufficient data available) but that its conservation status should be reassessed. Based on the present data the Sardinian newt would not meet the criteria for categorization as either Vulnerable $\left(\mathrm{AOO}<2\right.$,000 km², $\mathrm{EOO}<20,000 \mathrm{~km}^{2}$, with range severely fragmented; criteria $\mathrm{B}_{1}$ and $\mathrm{B}_{2}$ ) or Endangered. Regarding categorization as Endangered, criterion $\mathrm{A}$ is inadmissible because there are no demographic data available to infer trends for any populations, and criterion $\mathrm{B}$ is inadmissible because $\mathrm{EOO}>5,000 \mathrm{~km}^{2}(\mathrm{~B} 1)$ and AOO $>500 \mathrm{~km}^{2}\left(\mathrm{~B}_{2}\right)$. Only $\mathrm{B}_{2}$ sub-criterion $a$ (severely fragmented) is met. Criterion $\mathrm{C}$ is inadmissible because it is not known how many mature individuals occur in the wild; criterion D is inadmissible because the total population size could not be $<250$ mature individuals (we observed $>100$ mature individuals in a single creek); and criterion $\mathrm{E}$ is inadmissible because there are no quantitative demographic analyses. Thus a reassessment based on novel demographic data is needed.

\section{Overstatement of risk}

The categorization of the Sardinian newt as Endangered is based on the consideration of non-representative distribution data. Although this problem could be expected with rare species (Guisan et al., 2006) it is perhaps surprising that it can also arise with non-elusive and widespread species (Webb, 2008). There is a lack of information flow between national and global Red Lists, with the latter often not considering local data provided in national assessments (Rodríguez et al., 2000). However, our study highlighted a lack of information flow at a finer scale between national Red Lists and local repositories of species' distributional information, with data from wildlife experts, naturalist associations, and public services of environmental bodies being largely overlooked in Italian Red List assessments, resulting in overstatement of risk (Rondinini et al., 2013). For instance, the common toad Bufo bufo was categorized as Vulnerable because the assessors (Andreone et al., 2013a) concluded that the species was declining. The assessment was based on 30 populations within a narrow geographical range (Bonardi et al., 2011), monitored by volunteers protecting the toads against road traffic. However, the species is reported to be present in at least 1,472 Universal Transverse Mercator grid cells $\left(100 \mathrm{~km}^{2}\right.$; Sindaco et al., 2006). Even assuming that only a single population occurs in a single grid cell, only $2 \%$ of the Italian population was considered in the assessment. Furthermore, the assessment was biased because it considered only populations threatened by road traffic, which face a higher risk of decline than randomly selected populations. Bufo bufo should really be categorized as Least Concern. Similarly, the Tyrrhenian painted frog Discoglossus sardus was categorized as Vulnerable (Andreone et al., 2013b) on the basis of (1) habitat loss and Batrachochytrium infections, (2) $\mathrm{AOO}<2$,000 $\mathrm{km}^{2}$, and $(3)<10$ known locations of occurrence. However, this species is reported in 34 Universal Transverse Mercator grid cells (Sindaco et al., 2006) and was recorded by us, during opportunistic field activity, at $>50$ distinct sites (Supplementary Fig. S1). A categorization of Least Concern would be more appropriate for this species also. In both cases the national assessments were based on a subset of available knowledge about the species' distributions.

In general, to reduce the risk of overstating the level of threat to a species on the basis of partial information or subjective selection of non-representative data (as discussed here and in Webb, 2008), the data gathering process should 
be improved (Rodríguez et al., 200o) and perhaps the use of opportunistic data for Red List assessments (Maes et al., 2015) should be promoted. This could be done by making assessments available online for peer review or sending them directly to taxonomic or regional experts or IUCN Red List authorities (Brummitt et al., 2015). A public call for data in ongoing assessment procedures, with the distribution of appropriate questionnaires across local societies/ associations and other informed parties, would help to gather information for formal and transparent evaluation by assessors (Maes et al., 2015). A more open assessment procedure, with information-sharing between experts, would facilitate consensus regarding the interpretation of criteria, and limit bias (Hayward et al., 2015). Based on our experience we support the notion that a hierarchical procedure of data collection, from local repositories of species' distribution knowledge, through national assessments, to global Red Lists, should be adopted.

\section{Acknowledgements}

We are indebted to two anonymous referees for constructive reviews, and to Giovanni Amori, Massimo Capula, Claudia Corti, Spartaco Gippoliti, Lorenzo Rugiero and Roberto Sindaco for helpful discussion on the Italian Red List assessments. Giorgia Cadeddu kindly provided some of the data concerning the Sardinian distribution of Discoglossus sardus. LV and DM were funded by the European Association of Zoos and Aquaria.

\section{References}

Alcher, M. (1975) L'Urodèle Euproctus platycephalus (GRAVENHORST, 1829): repartition géographique et exigences thermiques. Vie et Milieu, 25, 169-179.

Amori, G., Gippoliti, S. \& Luiselli, L. (2014) A short review of the roles of climate and man in mammal extinctions during the Anthropocene. Rendiconti Lincei, 25, 95-99.

Anadón, J.D., Giménez, A., Ballestar, R. \& Pérez, I. (2009) Evaluation of local ecological knowledge as a method for collecting extensive data on animal abundance. Conservation Biology, 23, 617625.

Andreone, F. \& Luiselli, L. (2000) The Italian batrachofauna and its conservation status: a statistical assessment. Biological Conservation, 96, 197-208.

Andreone, F., Corti, C., Ficetola, F., Razzetti, E., Romano, A. \& Sindaco, R. (2013a) Bufo bufo. Lista Rossa dei Vertebrati italiani. Http://www.iucn.it/liste-rosse-italiane.php [accessed 2 March 2015].

Andreone, F., Corti, C., Ficetola, F., Razzetti, E., Romano, A. \& Sindaco, R. (2013b) Discoglossus sardus. Lista Rossa dei Vertebrati italiani. Http://www.iucn.it/liste-rosse-italiane.php [accessed 2 March 2015].

Bonardi, A., Manenti, R., Corbetta, A., Ferri, V., Fiacchini, D., Giovine, G. et al. (2011) Usefulness of volunteer data to measure the large scale decline of "common" toad populations. Biological Conservation, 144, 2328-2334.
Brummitt, N.A., Bachman, S.P., Griffiths-Lee, J., Lutz, M., MoAt, J.F, FArJon, A. et al. (2015) Green plants in the red: a baseline global assessment for the IUCN Sampled Red List Index for Plants. PLoS ONE, 10(8), eo135152.

Carranza, S. \& Amat, F. (2005) Taxonomy, biogeography and evolution of Euproctus (Amphibia: Salamandridae), with the resurrection of the genus Calotriton and the description of a new endemic species from the Iberian Peninsula. Zoological Journal of the Linnean Society, 145, 555-582.

Casula, P., Angelini, C., Bovero, S., Sotgiu, G., Sabatini, A., Palmas, F. et al. (2010) Euproctus platycephalus (Amphibia, Urodela): Piano di Conservazione. Technical report, Ente Foreste della Sardegna, Assessorato della Difesa dell'Ambiente RAS, Cagliari, Italy.

Cox, N.A. \& Temple, H.J. (2009) European Red List of Reptiles. Office for Official Publications of the European Communities, Luxembourg.

De Pous, P., Speybroeck, J., Bogaerts, S., Pasmans, F., Beukema, W. (2012) A contribution to the atlas of the terrestrial herpetofauna of Sardinia. Herpetology Notes, 5, 391-405.

Franco, D., Akani, G.C., Ebere, N. \& Luiselli, L. (2013) Using the river Niger delta local communities' ecological knowledge to support the scientific evidence of snake declines. Herpetozoa, 25, 133-142.

Guisan, A., Broennimann, O., Engler, R., Vust, M., Yoccoz, N. G., Lehmann, A. \& Zimmermann, N.E. (2006) Using niche-based models to improve the sampling of rare species. Conservation Biology, 20, 501-511.

Hayward, M.W., Child, M.F., Kerley, G.I.H., Lindsey, P.A., Somers, M.J. \& Burns, B. (2015) Ambiguity in guideline definitions introduces assessor bias and influences consistency in IUCN Red List status assessments. Frontiers in Ecology and Evolution, 3, 87.

Hoffmann, M., Hilton-Taylor, C., Angulo, A., Böhm, M., Brooks, T.M., Butchart, S.H.M. et al. (2010) The impact of conservation on the status of the world's vertebrates. Science, 330, 1503-1509.

Huntington, H.P. (200o) Using traditional ecological knowledge in science: methods and applications. Ecological Applications, 10, 12701274.

IUCN (2012) IUCN Red List Categories and Criteria Version 3.1. 2nd edition. IUCN, Gland, Switzerland \& Cambridge, UK.

IUCN (2015) The IUCN Red List of Threatened Species v. 2015-4. Http://www.iucnredlist.org [accessed 3 February 2016].

IUCN SSC Amphibian Specialist Group (2011) The IUCN Red List of Threatened Species v. 2015-4. Http://www.iucnredlist.org [accessed 3 February 2016].

Lecis, R. \& Norris, K. (2003) Geographical distribution of the endemic Sardinian brook salamander, Euproctus platycephalus, and implications for its conservation. Herpetological Journal, 13, 125-133.

LECIS, R. \& NorRIS, K. (2004) Habitat correlates of distribution and local population decline of the endemic Sardinian newt Euproctus platycephalus. Biological Conservation, 115, 303-317.

Luiselli, L. (2009) A model assessing the conservation threats to freshwater turtles of sub-Saharan Africa predicts urgent need for continental conservation planning. Biodiversity \& Conservation, 18, 1349-1360.

Maes, D., Isaac, N.J.B., Harrower, C.A., Collen, B., van Strien, A.J. \& Roy, D.B. (2015) The use of opportunistic data for IUCN Red List assessments. Biological Journal of the Linnean Society, 115, 690706.

Manne, L.L., Brooks, T.M. \& Pimm, S.L. (1999) Relative risk of extinction of passerine birds on continents and islands. Nature, 399, 258-261. 
PRIMACK, R.B. (2006) Essentials of Conservation Biology. Sinauer Associates, Inc., Sunderland, USA.

Rodríguez, J.P., Ashenfelter, G., Rojas-Suárez, F., García FernándeZ, J.J., SuÁrez, L., Dobson, A.P. (2000) Local data are vital to worldwide conservation. Nature, 403, 241.

Romano, A., Sindaco, R., Andreone, F., Lecis, R., Edgar, P., Schmidt, B. \& Corti, C. (2009) Euproctus platycephalus. In The IUCN Red List of Threatened Species v. 2014.3. Http://www. iucnredlist.org [accessed 2 March 2015].

Rondinini, C., Battistoni, A., Peronace, V. \& Teofili, C. (2013) Lista Rossa dei Vertebrati italiani. Http://www.iucn.it/ liste-rosse-italiane.php [accessed 2 March 2015].

SARdegna Foreste (2010) Euprotto Sardo: chi l'ha visto? Http://www. sardegnaambiente.it $/ \mathrm{j} / \mathrm{v} / 152 ? \mathrm{~s}=133761 \& \mathrm{v}=2 \& \mathrm{c}=1546 \& \mathrm{t}=1$ [accessed 4 February 2016].

Simberloff, D. (200o) Global climate change and introduced species in United States forests. Science of the Total Environment, 262, 253261.

Sindaco, R., Doria, G., Razzetti, E. \& Bernini, F. (2006) Atlante degli Anfibi e dei Rettili d'Italia/Atlas of Italian Amphibians and Reptiles. Societas Herpetologica Italica, Edizioni Polistampa, Florence, Italy.

Sotgiu, G., Bovero, S., Bielby, J., Doglio, S., Favelli, M., Garner, T. et al. (2010) Dati aggiornati sulla distribuzione di Euproctus platycephalus. In Atti VIII Congresso Nazionale Societas Herpetologica Italica (Chieti, 22-26 settembre 2010) (eds L. Di Tizio, A.R. Di Cerbo, N. Di Francesco \& A. Cameli), pp. 27-29. Ianieri Edizioni, Pescara, Italy.

Stuart, S.N., Chanson, J.S., Cox, N.A., Young, B.E., Rodrigues, A.S.L., Fischman, D.L. \& Waller, R.W. (2004) Status and trends of amphibian declines and extinctions worldwide. Science, 306, 1783-1786.
Tomović, L., Urošević, A., Vukov, T., Ajtić, R., Ljubisavljević, K., KRIZMAnić, I. et al. (2015) Threatening levels and extinction risks based on distributional, ecological and life-history datasets (DELH) versus IUCN criteria: example of Serbian reptiles. Biodiversity \& Conservation, 24, 2913-2934.

Weвв, G.J.V. (2008) The dilemma of accuracy in IUCN Red List categories, as exemplified by hawksbill turtles Eretmochelys imbricata. Endangered Species Research, 6, 161-172.

White, P.C.L., Jennings, N.V., Renwick, A.R. \& Barker, N.H.L. (2005) REVIEW: Questionnaires in ecology: a review of past use and recommendations for best practice. Journal of Applied Ecology, 42, 421-430.

\section{Biographical sketches}

LEONARDO VIGNOLI studies the ecology and behaviour of amphibians and reptiles. His interests range from feeding and reproductive ecology to management and conservation, and he is currently involved in several amphibian and reptile conservation projects. DANIELE MACALE is head keeper at the reptile house at Bioparco di Roma, where he is in charge of all ex situ conservation projects involving amphibians and reptiles. LUCA LUISELLI is a tropical ecologist working on aspects of community ecology and conservation in tropical ecosystems, particularly in West Africa. He also works on the conservation ecology of Italian reptiles and amphibians. ROB ER T A LECIs' research focuses on wildlife health, molecular microbiology, epidemiology and conservation genetics, and she is interested in the conservation of threatened island endemic species and their habitats. PAOLO CASULA is an ecologist working on biodiversity conservation and monitoring for the Sardinian forest management agency, Ente Foreste della Sardegna. 